Article

\title{
Civil Society in Hybrid Governance: Non-Governmental Organization (NGO) Legitimacy in Mediating Wal-Mart's Local Produce Supply Chains in Honduras
}

\section{J. Dara Bloom}

Department of Youth, Family, and Community Sciences, College of Agriculture and Life Sciences, North Carolina State University, Campus Box 7606, Raleigh, NC 27695, USA;

E-Mail: dara_bloom@ncsu.edu; Tel.: +1-919-515-8475; Fax: +1-919-515-7812

External Editors: Douglas H. Constance and Maki Hatanaka

Received: 28 August 2014; in revised form: 8 October 2014 / Accepted: 14 October 2014 /

Published: 23 October 2014

\begin{abstract}
This paper challenges the notion that the incorporation of actors from civil society into hybrid governance arrangements improves outcomes and legitimacy. Multi-stakeholder collaborations are a popular hybrid governance approach to development, including NGOs' work to integrate smallholder farmers into supermarket supply chains. As a result, NGOs' service provision role has expanded to include market facilitation, often necessitating NGOs act as market intermediaries. This paper explores how this new role may jeopardize NGOs' organizational legitimacy in the eyes of their constituents, other development organizations, and supermarket partners, and therefore ultimately affect their ability to represent civil society in hybrid governance arrangements. Drawing on qualitative data collected in the Central American country of Honduras, this paper focuses on NGOs' role organizing producer associations to facilitate access to Wal-Mart supermarkets. Findings suggest that a lack of supply chain transparency, NGOs' negotiation between commercial and aid-oriented goals, and the potential to exclude producers from development projects threaten NGOs' legitimacy. These findings illustrate the difficulties of embedding philanthropic activities in market-based systems, and demonstrate how multi-stakeholder collaborations may be influenced more by commercial priorities than the elements of a partnership. Ultimately, development NGOs are products of neoliberal, hybrid governance, even as their activities are expected to ease the transition of small-scale producers into this system.
\end{abstract}


Keywords: market-based development; supermarket retailers; Latin America; multi-stakeholder collaborations; organizational legitimacy; Wal-Mart

\section{Introduction}

As supermarket retailers expand in countries in the Global South, sourcing produce locally both fulfills Corporate Social Responsibility (CSR) goals and improves domestic procurement systems. These corporate retail interests coincide with the activities of development Non-Governmental Organizations (NGOs) that connect producers to markets as a strategy to address rural poverty [1-4]. This convergence of interests between market actors and civil society organizations coincides with broader shifts in global governance: the nation state's role has largely shifted away from a command-and-control regulatory regime towards facilitating the context and conditions of market-based regulations; as a result, responsibility and authority for regulating societal interactions have largely shifted to private actors and hybrid governance arrangements [5-8]. Increasingly, market-based development projects are implemented as hybrid, multi-stakeholder collaborations in which the nation state's role is to partner with civil society organizations and market actors to facilitate smallholder participation in supply chains $[3,4,9,10]$.

Multi-stakeholder collaborations are often referred to as a form of hybrid governance, a recognition that in the neoliberal era, governance roles are not concentrated in the entity of the nation state, but rather are diffuse and often shared among actors from multiple sectors $[6,7,11,12]$. The assumption is that civil society's involvement in hybrid governance contributes accountability and legitimacy, and therefore improves the effectiveness of hybrid governance [5,13-15]. However, in the context of market-based development projects, there can be competing visions between actors from the private sector, who operate according to business logic, and those from civil society, whose role has traditionally been more aid-oriented [9,16,17]. J. Brinkerhoff suggests that these competing dynamics are some of the least studied aspects of governance in multi-stakeholder collaborations, and as a result she suggests a more nuanced definition of governance specific to this context: "Governance is fundamentally about managing competing interests for the common good" [18] (p. 68).

This paper examines how NGOs, as representatives of civil society in multi-stakeholder collaborations, "manage competing interests for the common good" by negotiating between commercial and aid-oriented goals in market-based development projects. As supermarket retailers expand their domestic sourcing in developing country markets, NGOs' traditional service provision role has expanded to include that of market facilitation, which often necessitates that these civil society organizations serve as market intermediaries. This paper problematizes the role of NGOs as market facilitators, and explores how the commercial pressures of market-based development projects may jeopardize NGO organizational legitimacy in the eyes of their constituents, other development organizations, and supermarket partners. The issue of how to evaluate legitimacy in multi-stakeholder collaborations has recently been identified as a priority within the study of private agri-food governance [19,20]. However, research in this area has primarily focused more on issues of legitimacy in standards-setting collaborations or public/private partnerships, which often occur at a global, transnational scale [5,6,14,21-23], and less on questions of 
organizational legitimacy for participating organizations operating on the ground, a gap in the literature that this paper will address [24].

For this analysis, I draw on research conducted in the Central American country of Honduras, which examined the relationships between small-scale producers, NGOs, and the Wal-Mart Corporation in local produce supply chains. These relationships were developed in the context of multi-stakeholder collaborations that have the goals of promoting rural development by fostering the creation of producers' associations that facilitate the inclusion of smallholder farmers in Wal-Mart's local supply chains. Findings from this research suggest that NGOs take on a vertical role in supply chain coordination when organizing producers' associations and mediating their relationships with supermarkets. NGOs' role as market intermediaries raises questions about how these organizations negotiate competing goals, how they distribute benefits, and what effect these activities might have on civil society organizations' legitimacy in the context of hybrid governance. I suggest that NGOs' performance of market activities, and the potential subsequent challenge to their legitimacy, can call into question NGOs' role as representatives of civil society, and therefore the essence of civil society participation in hybrid governance.

This paper proceeds by reviewing the concept of hybrid governance, as well as clarifying the concept of civil society and its relationship to the role of NGOs in multi-stakeholder collaborations. I then turn to theories of organizational legitimacy and the cognitive dimension of social evaluations of legitimacy to analyze the effect of NGOs' new roles in market-based development on how they are perceived. I then apply this framework to research from Honduras, before turning to a discussion of the implications of hybrid governance for NGO legitimacy and the role of civil society in multi-stakeholder collaborations.

\section{Background Literature}

\subsection{Hybrid Governance and Civil Society}

The increasing prominence of private and civil society actors jointly governing international development projects can be understood in the wider context of shifts in the global governance of environmental and social problems. Many theorists have challenged the notion that power was ever fully concentrated in the political institution of the government, and consequently the concept of "governance" has emerged to apply ideas about authority, power, and regulation to the now prominent emphasis on market-based systems and multi-stakeholder collaborations [25-28]. While it is common to describe the perceived shift of power and authority from the nation state to private industry as the rise of private over public governance, the term hybrid governance more accurately conveys the complexities of the continued role of the state and the insertion of civil society into these otherwise private arrangements $[5,7,25,29]$.

Multi-stakeholder collaborations often take the form of public/private partnerships (PPPs), for example in the form of water privatization projects or third party certification systems [10,30-32]. Since PPPs help to provide public goods, they are often seen as filling a regulatory gap resulting from the gradual withdrawal of national governments from the provision of public services [9,33-35]. As a result, PPPs are often described as "win-win" responses to both state and market failures, improving the efficiency and effectiveness of public service provision [15,31,35,36]. For example, national governments in developing countries largely transferred responsibility for providing social services, such as agricultural extension, 
towards private and non-profit actors in response to internationally imposed structural adjustment policies $[9,33,34,37]$.

In this context, organizations from civil society are often seen as providing a check to the self-regulating market, enhancing the legitimacy of hybrid governance arrangements by prioritizing the interests of marginalized populations $[14,15,38]$. In contrast, some scholars have suggested that multi-stakeholder collaborations are neoliberal constructs that reproduce the power dynamics that are inherent within the global economy by privileging the interests of corporations and governments from the Global North over the needs of more disadvantaged people and communities in the Global South [38,39]. These diverging views of the role that civil society plays in hybrid governance suggest the need to explore more thoroughly the concept of civil society, including NGOs' claims to representation.

\subsection{Civil Society and the Role of $N G O s$}

The term "civil society" in development discourses refers to a sector that is distinct from, though related to, the political and economic sectors $[13,40]$. Civil society is understood as a network of voluntaristic associations; these associations are considered "voluntary" both in that membership is consensual, not obligatory, and in that the association itself must engage in voluntaristic strategies to achieve its goals (unlike the state, which can legislate, or the market, which can provide incentives) [13]. Although civil society, as this associational sphere, therefore encompasses a wide array of organizations and institutions, the term is most often used to describe the non-profit sector and social and grassroots movements. Also referred to as the "third way" and "compassionate conservatism", a reliance on civil society to compensate for the negative repercussions of the rise of market-based governance assumes that "partnership between all three sectors working together-public, private and civic — is the best way to overcome social and economic problems" [13] (p. 22).

This definition of civil society leads to the question of the basis of NGOs' claim to represent civil society in hybrid governance arrangements. NGOs are: "self-governing, private, not-for-profit organizations that are geared to improving the quality of life of disadvantaged people" [41] (p. 2060). Vakil makes a point of distinguishing between "not-for-profit" and non-profit in this definition, since she maintains that an organization such as a cooperative can be a not-for-profit organization in terms of its mission, while still generating and distributing a profit to its members. The activities that NGOs engage in include: providing aid, often in an emergency capacity after a disaster; providing services to enhance capacity-building for self-reliance; and focusing on policy change with an orientation towards advocacy [41-43]. The development literature most often refers to service organizations that focus on capacity-building when discussing NGOs, and research has suggested that service-provision NGOs are more likely to be invited to participate in PPPs than advocacy NGOs [41,44].

Because of their role in development, the term NGO has become "a claim-bearing label":

In its most common use, it claims that the organization is doing good for the development of others. The label has a moral component. Precisely because it is doing good, the organization can make a bid to access funding and public representation [45] (p. 290).

NGOs' involvement with organizing producers and connecting them with markets is often mentioned as a way to shift the balance of power between supermarkets and producers $[9,46,47]$, and is seen as part 
of a larger goal of "making markets work for the poor" [3] (p. 16). In this context, NGOs have been described as "neutral" actors from civil society whose mediation of relationships between growers and large buyers can enhance the outcomes and benefits of these arrangements [47]. Even beyond claims to neutrality, some suggest that "NGOs have assumed [the role] of representing the needs and aspirations of what is inevitably understood as the citizenry of a not-yet-realized global political order" [45] (p. 286).

On the other hand, when NGO activities deviate from socially accepted roles, this can challenge their public image, and legitimacy, as representatives of civil society. NGOs originally emerged as non-profit organizations with close relationships with grassroots and peasant movements $[13,48,49]$. However, as these organizations were increasingly expected to perform functions that were previously relegated to the state, they faced the need to scale-up and professionalize their operations $[12,48]$. This process of professionalization can be understood within the context of the mainstreaming of the environmental movement, which dissipated the more radical, activist focus of the movement and institutionalized it within NGOs and global environmental organizations [12]. Many of the environmental movement's priorities were channeled into the sustainable development project, which brought together organizations from multiple sectors and defined integration and engagement with economic systems as the most efficient means to effect environmental and social change [12]. In addition to professionalization, this introduced an entrepreneurial approach to the development project, and the promotion of market-based projects [12].

The professionalization and increasingly market-based approach of NGOs led to a disjuncture in many cases between NGOs and the popular movements they were assumed to represent, which has been described as a process of de-politicization or NGO-ization $[13,37,48,49]$. In their study of NGOs in Nicaragua, Chahim and Prakash compare NGOs and grassroots organizations, and found that due to pressures of foreign donors and the fact that NGOs are seen as a one-way transfer of information and services, their constituents felt disconnected from the NGO. These authors suggest that as a result, the concept of civil society is becoming less about community participation, and 'is instead a 'project', a means to 'resolve and finance' instrumental, short-term problems, not a means to achieve long-term structural change" [37] (p. 21).

Despite the fact that NGOs may struggle to fulfill their role as representatives of civil society, they continue to be invited to participate in multi-stakeholder collaborations on this basis. It is possible that multi-stakeholder collaborations that include NGO participation may tend to romanticize NGOs' ability to represent the interests of civil society, and thereby the legitimacy of new governance arrangements, without adequately exploring the complex terrain that NGOs are expected to navigate. Just as the professionalization and de-politicization of NGOs drew into question their ability to represent civil society in the 1990s, market-based development in the context of hybrid governance arrangements requires of NGOs a new set of responsibilities and activities, which could lead to a new round of legitimacy challenges. Therefore, it is important to analyze how these new responsibilities and activities may affect NGOs' claims to legitimacy and civil society representation.

\subsection{New Roles of NGOs in Hybrid Governance and Market-Based Development}

One of the roles that NGOs increasingly play in the context of multi-stakeholder collaborations is to organize producers into associations to facilitate their access to large markets $[9,33,50]$. This activity is also described in research on contract agricultural arrangements, where NGO involvement is seen as 
critical to mediating informal agreements between small-scale producers and large buyers $[46,47]$. Producers' associations perform the dual function of facilitating transfer of information and resources to producers and serving as aggregation and distribution centers to increase efficiencies and economies of scale. In addition, they are believed to increase the bargaining power of small-scale producers vis-à-vis large buyers, thus strengthening their market position [2-4,9]. While most producer organizations are member-owned, research has shown that third party facilitation is crucial to the success of these producer organizations, although continued financial support by this third party can keep producer organizations from achieving financial sustainability and autonomy [4,9,46,47].

There is some debate about whether the government, NGOs or private companies are best positioned to facilitate producers' associations. Most researchers agree that NGOs are most often ideal facilitators since, "not all outsiders are seeking to maximize the returns to the community. Commercial agents higher up the commodity chain are particularly likely to have a conflict of interest with farmers over the distribution of surplus along the commodity chain from producer to consumer" [9] (p. 5). However, the introduction of a commercial logic into development projects has implications for how the benefits of such projects are distributed, including the potential exclusion of more marginalized, low-income populations $[2,9,10,31,47,51]$. Participating in producers' associations and selling to supermarkets often requires certain assets and capabilities on the part of producers that may preclude the more marginalized from participating $[9,33,47]$. Often this is related to the fact that small-scale producers lack the financial or natural resources to be able to comply with buyers' standards, such as those regarding food safety, and this can lead to their exclusion from development projects and these potentially lucrative marketing channels [52-55].

\subsection{A Framework for Analyzing the Legitimacy of NGOs}

The definition, history, and relationship between NGOs and civil society in the context of development are important for understanding these organizations' legitimacy claims, as well as how their activities in hybrid governance arrangements might lead some to challenge these claims. Traditional scholarship on legitimacy was state-focused, and some have used this as the basis for criticizing NGOs and multi-stakeholder collaborations for failing to meet the premises of democratic legitimacy. These criticisms suggest that civil society organizations are managed by unelected representatives, and therefore don't demonstrate the democratic values of participation, accountability, and transparency in the decision-making process $[15,21,38,42]$. However, Bäckstrand [38] suggests that it is illogical to judge partnerships on the same basis as democratic institutions, since doing so fails to consider the new regulatory space that multi-stakeholder arrangements occupy outside of a state-based system. Therefore, in order to develop a framework for assessing NGO legitimacy, we can turn to scholarship on organizational legitimacy that goes beyond a consideration of criteria that were derived from analysis of state legitimacy.

In organizational sociology, Suchman's definition of legitimacy has been very influential, and is widely cited [6,14,24,56,57]: "Legitimacy is a generalized perception or assumption that the actions of an entity are desirable, proper, or appropriate within some socially constructed system of norms, values, beliefs, and definitions" [58] (p. 574). In this sense, legitimacy is socially constructed, and therefore perceptions are an important aspect for how it is judged [14,58]. Suchman distinguishes three types of legitimacy: pragmatic, moral, and cognitive. Pragmatic legitimacy concerns the self-interest of the audience that is 
evaluating an organization, and relates to this audience's belief that it will benefit from the organization's activities. Moral legitimacy relates to the value system of the evaluating audience, and whether there are benefits to society generated because "the activity is "the right thing to do" [58] (p. 579). Finally, cognitive legitimacy is a more subtle form of legitimacy, since it relates to a state of "taken-for-grantedness" where an audience is easily able to classify an organization according to pre-existing, accepted, social categories [58].

Bitektine [56] expands upon these aspects of legitimacy to develop a cognitive theory of how individuals make social judgments. These individuals constitute the audiences that might evaluate an organization, and in the case of NGOs could include their constituents, donor agencies, partners and local government representatives [24,56]. Bitektine's model of social judgment formation provides a useful framework for understanding the step-by-step process of how individuals may assess the legitimacy of NGOs in multi-stakeholder collaborations as they assume a market-oriented role.

\subsubsection{Step 1: Cognitive Legitimacy}

In Bitektine's theory, individuals begin evaluating an organization in terms of cognitive legitimacy, attempting to classify an organization into an easily identifiable, pre-defined category. Judging an NGO's cognitive legitimacy is related to the earlier discussion about the definition and role of NGOs in the development context, and the basis of their claims as representatives of civil society. In this sense, NGOs' claims to legitimacy are precisely what distinguishes them from either the state or market actors, specifically because their relationship to civil society is, "based on the recognition and promotion of the rights or moral claims of others, such as or including 'development rights' or the right to participate in and benefit from social and economic change" [42] (p. 860). However, as NGOs that participate in market-based development increasingly take on commercial roles in partnerships, it is possible that this market-orientation may preclude an evaluator's ability to fit them neatly into the category of civil society representatives. Many scholars make use of the term "liability of newness", to describe a situation such as this, where an organization takes on new activities and must establish the legitimacy of both these new activities and its right to perform them [24,58]. In the case of NGOs that take on commercial roles, this could be particularly true if evaluators perceive that these new activities lead to "mission drift" [24], or the failure of an organization to execute the role for which it was established, and based on which it receives support [57].

\subsubsection{Step 2: Sociopolitical (Pragmatic and Moral) Legitimacy}

If attempts to evaluate cognitive legitimacy fail, Bitektine suggests that an individual performing an evaluation might assess the organization according to a more complicated set of criteria, which he refers to as sociopolitical legitimacy. Bitektine's concept of sociopolitical legitimacy is based on whether, "the organization is beneficial to the evaluator, his or her social group, and/or the whole society" [56] (p. 158), which in essence combines Suchman's pragmatic [58] and moral legitimacies. Suchman suggests that there are several avenues for assessing moral legitimacy, including an analysis of the outcomes, procedures, and structures of an organization. Others have expanded these aspects of moral legitimacy to include accountability and effectiveness as appropriate metrics by which to evaluate NGO legitimacy $[18,38,42]$. Suchman emphasizes that these aspects of moral legitimacy relate to conformity with socially 
constructed norms and values, and that the techniques an organization uses, as well as the consequences of its activities, will help to establish the perception that it is "the right organization for the job" [58] (p. 581).

By applying these concepts to an analysis of NGO legitimacy, we can break down accountability into its internal and external aspects. Internal accountability refers to the responsibility that an organization has to its members (shareholders, in the case of corporations, or program beneficiaries, in the case of NGOs), and external accountability in relation to the public (including citizens and governments $[5,14,18,21]$. Studies of NGOs suggest that they often struggle to balance their upward accountability to donors and their downward accountability to their constituents, often prioritizing the former in order to preserve their funding sources $[37,41,42]$. Studies of accountability also emphasize the importance of transparency to ensure that both internal and external actors trust the procedures that organizations establish, and ultimately to determine whether actors have enough information to be able to judge whether they consider an organization to be legitimate $[5,18,38,41,48]$. In this case, "transparency and accountability are closely linked, as accountability hinges on access to information" [5] (p. 300). Finally, in terms of evaluating NGO outcomes and effectiveness, previous studies suggest that NGOs and partnerships focus both on measuring tangible metrics (for example, an increase in income) as well as more intangible elements (such as empowerment of constituents [42]. In addition, effectiveness has also been evaluated in terms of NGOs' or partnerships' ability to change systems, policies, or corporate operations [17,24].

\subsubsection{Step 3: Legitimacy Crises}

If an organization fails to meet the criteria for establishing cognitive or sociopolitical legitimacy, this may lead to challenges, and ultimately a crisis, in legitimacy. There is a wide spectrum in the consequences of a challenge to an organization's legitimacy that depends largely on context. For example, if an individual feels that an organization fails to meet his/her standards for legitimacy, but this is not a view shared by the general public, there may be few consequences [56,58]. In addition, in evaluations of legitimacy some actors or groups carry more weight than others, and therefore an organization can survive threats to its legitimacy if it has the support of key groups, even though it may have individual detractors [24,56]. On the other hand, if an organization is judged to be illegitimate by key audiences, there may be more tangible sanctions, ranging from losing support and funding to difficulties in attracting either partners or participants for an organization's activities [24,56,57].

Alternately, if an organization fails to meet the standards of cognitive legitimacy, this could "lead to an expansion of the set of considered categories" [56] (p. 165). For example, in his analysis of the legitimacy crisis facing Latin American NGOs in the 1980s and 1990s, Bebbington [48] suggested that NGOs might address this crisis by shifting their activities to a completely different category of organization. Since peasant communities perceived these NGOs to be very much aligned with the state and less so with civil society interests, Bebbington suggested that these organizations might instead become social enterprises that engaged with the market in order to expand benefits to the rural poor. However, in doing so he also states that,

These new social enterprise institutions can no longer be considered as NGOs in the traditional sense of the term. Yet, these institutions are also neither wholly state- nor wholly market-driven. They combine a commercial and a social logic in their operations which allows them to play a role which is not open to either the state or the market [48] (p. 1760). 
Ultimately, therefore, challenges to legitimacy can lead to a re-orientation in organizational identity, and attempts to re-establish legitimacy by creating a new, socially acceptable category.

This review of the literature has established the basis for analyzing the expanded role of NGOs in multi-stakeholder collaborations, and the potential effects that serving as a market intermediary might have on these organizations' legitimacy, and ultimately their basis for representing civil society in hybrid governance arrangements. I next turn to the case of Wal-Mart in Honduras, and qualitative fieldwork that explores the challenges that NGOs face in meeting the expectations of supermarkets, funders, and small-scale producers.

\section{Wal-Mart in Honduras: Context and Methods}

For its international operations, Wal-Mart's sustainability goal for its agri-food supply chains primarily revolves around sourcing more products from local growers in emerging markets, including providing training in sustainable practices to increase producer incomes [59]. Wal-Mart has provided some technical assistance to small-scale farmers through a regional subsidiary distribution company, Hortifruti, [60] which Wal-Mart acquired when it bought out a Central American retailer in 2005 [61].

In recent years, most technical assistance has been outsourced through Wal-Mart's partnerships with development projects, demonstrating the shift in governance first from the public sector to private actors, and now to a hybrid form [62-64]. Wal-Mart's partnerships include those with US agencies, such as the United States Agency for International Development (USAID), the United States Department of Agriculture (USDA), and the Millennium Challenge Corporation (see Figure 1 for a summarized schematic of the organization of these development projects). These agencies in turn subcontract project management to US-based and regional (Central American) NGOs, non-profit organizations, and consulting companies. Subcontracting organizations then bring together development NGOs and sometimes a local university to implement the project, combining support from the US government with funding from other foreign governments, local governments, and international NGOs and organizations, such as Oxfam and the Inter-American Development Bank. Development projects and organizations, in turn, organize producers into associations [65] intended to facilitate their ability to sell to Wal-Mart, and simultaneously help Wal-Mart expand its domestic supplier base [66].

The findings presented in this paper are based on fieldwork I conducted in Honduras between July and November of 2011. For the purposes of this paper, I focus on four producers' associations that were actively coordinated by outside organizations (see Table 1). Three of these associations were coordinated by NGOs that operate on a national scale and can be classified as service organizations, since their mission statements describe themselves as not-for-profit and providing capacity-building assistance to increase self-reliance and empowerment of their constituents. The fourth association, Producers' Association $\mathrm{C}$, is coordinated by an aid agency of a foreign government that works with other local organizations to provide services, including humanitarian, emergency aid, and capacity-building activities. This organization is therefore not officially an NGO, although its employees performed similar activities as the other NGO employees interviewed in this study in terms of their facilitation of a producers' association, and faced similar challenges to balancing commercial and aid-oriented goals; therefore their perspectives are considered relevant for analyzing the organizational challenges and implications of connecting producers to supermarkets as part of market-based development projects in the context of 
hybrid governance arrangements. For these reasons, I refer to this organization as an agency in the subsequent sections, and to the other three as NGOs.

Figure 1. Summarized schematic of development project organization and funding streams in Honduras.

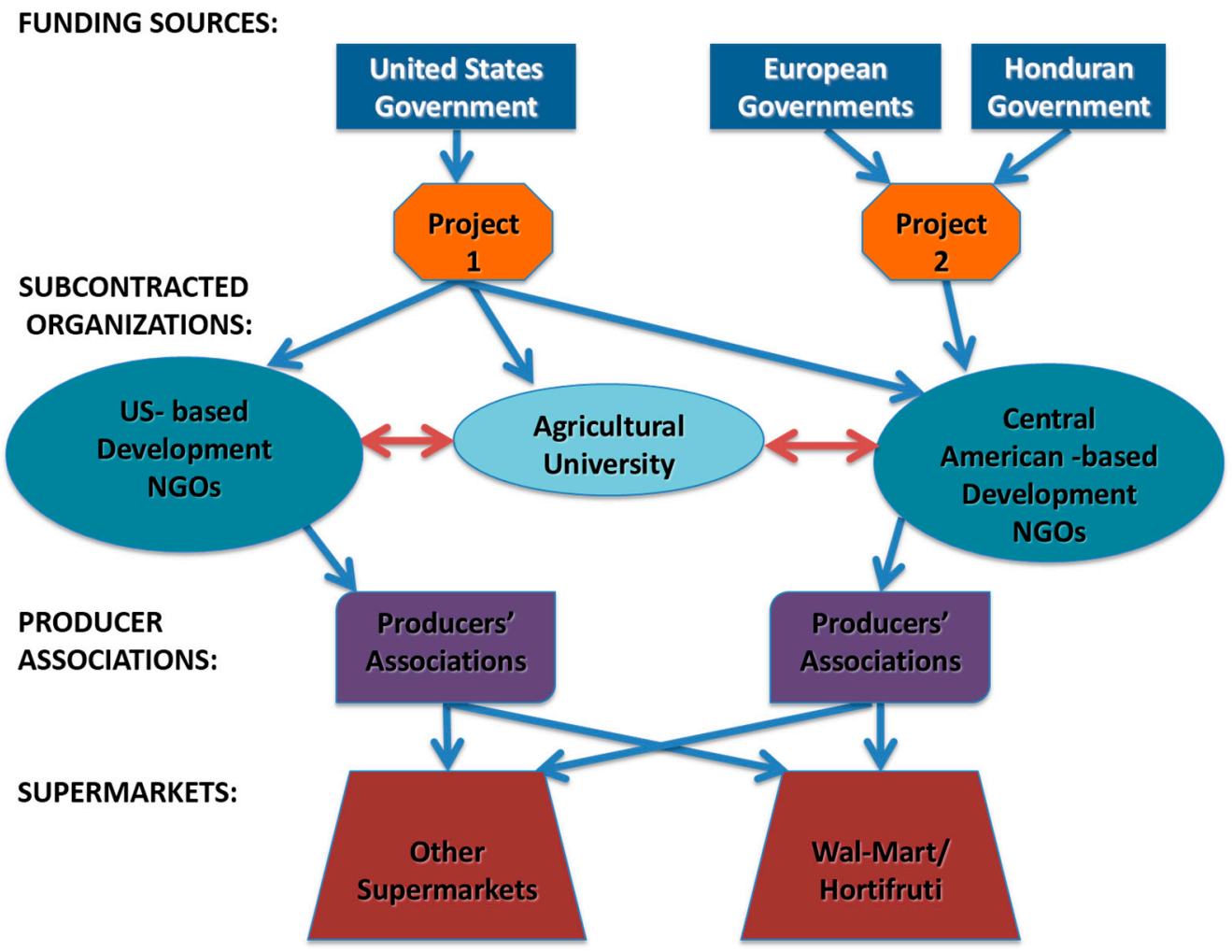

For the four producers' associations, contact was initially made with the NGO or agency organizing the associations, who in turn facilitated access to the producers with whom they worked. I conducted semi-structured interviews with eight NGO and agency representatives [67] and ten producers (three of whom held leadership positions within their association), as well as three employees who coordinated production and marketing among several NGOs for the most recent USAID project (who were formally employees of the sub-contracted US-based consulting company that managed this project, and who are not listed in Table 1), for a total of 21 individual interviews [68]. Interviews lasted an hour, on average, and were taped, transcribed verbatim and uploaded into NVivo 10, a software program that facilitates the analysis of qualitative data. Data were analyzed according to pre-determined, theoretically driven, and emergent themes [69].

As described in Table 1, the average length of time that individual producers had been selling to producers' associations varied, as did the length of time the associations themselves had been in operation. Producers' associations also differed by the markets to which they sold, with one (Producers' Association A) selling exclusively to Hortifruti, and another (Producers' Association C) selling consistently to Hortifruti, among other supermarkets. While there were no formal contracts for any of these associations, the NGO that worked with Producers' Association A was able to establish an informal agreement with Hortifruti that included negotiating a pre-season planting schedule and price range for products. Producers' Association B sold to Hortifruti only once; it had discontinued the relationship due 
to a bad experience. For Producers' Association D, the facilitating NGO had an established relationship with another supermarket, although some individuals within the association continued to sell directly to Hortifruti. Although Producers' Association B had sold to Hortifruti only once and Producers' Association D did not have a formal commercial relationship with Hortifruti, they were included in this study in keeping with Bolwig et al.'s suggestion that analysis should include both "expelled actors" and "non-participants/excluded actors," to fully understand the implications that supply chain governance has on poverty and rural development in local contexts [52] (p. 185).

Table 1. Sample Characterisitcs of NGO-facilitated Producers' Associations in Honduras.

\begin{tabular}{|c|c|c|c|c|c|c|}
\hline $\begin{array}{l}\text { Association } \\
\text { Pseudonym }\end{array}$ & $\begin{array}{l}\text { Number of } \\
\text { NGO/Agency } \\
\text { Representatives } \\
\text { Interviewed } \\
\end{array}$ & $\begin{array}{l}\text { Years } \\
\text { Association } \\
\text { Has Been } \\
\text { Operating } \\
\end{array}$ & $\begin{array}{l}\text { Markets Association } \\
\text { Sold To }\end{array}$ & $\begin{array}{l}\text { Number of } \\
\text { Producer } \\
\text { Members in } \\
\text { Association } \\
\end{array}$ & $\begin{array}{l}\text { Number of } \\
\text { Producer } \\
\text { Members } \\
\text { Interviewed } \\
\end{array}$ & $\begin{array}{l}\text { Average Years } \\
\text { Interviewed } \\
\text { Producers Sold } \\
\text { to Association } \\
\end{array}$ \\
\hline $\begin{array}{l}\text { Producers' } \\
\text { Association A }\end{array}$ & 3 & 5 & Hortifruti & 45 & 3 & 1 \\
\hline $\begin{array}{l}\text { Producers' } \\
\text { Association B }\end{array}$ & 2 & 3 & $\begin{array}{l}\text { Other Supermarkets } \\
\text { (Hortifruti Once) }\end{array}$ & $\begin{array}{c}120(15-25 \\
\text { full time }) \\
\end{array}$ & 3 & 3 \\
\hline $\begin{array}{l}\text { Producers' } \\
\text { Association C }\end{array}$ & 2 & 3 & $\begin{array}{l}\text { Hortifruti and Other } \\
\text { Supermarkets }\end{array}$ & 116 & 1 & 3 \\
\hline $\begin{array}{l}\text { Producers' } \\
\text { Association D }\end{array}$ & 1 & 5 & $\begin{array}{l}\text { Other Supermarket } \\
\text { (Individuals sold } \\
\text { directly to Hortifruti) }\end{array}$ & 100 & 3 & 2 \\
\hline
\end{tabular}

In general, the NGO and agency representatives emphasized that they saw their role organizing and managing producers' associations as a necessary, but temporary, arrangement that would last only until ownership and management of the producers' association could be transferred to the participating growers. They explained this emphasis on transitioning to self-management alternately as a condition of the external funding that they received, or as a response to concerns within development projects about avoiding paternalism and dependency $[42,45]$. In this study, the NGO and agency representatives who coordinated Producers' Associations B and C planned on transitioning management to participating producers within the year that this research was conducted, while NGOs remained more active in managing commercial relationships for Producers' Associations A and D. Therefore, while it is important to note that NGO representatives did not see their market intermediary roles as a long-term function, at the time of this study all remained actively involved with market mediation for all four of these producers' associations.

\section{Findings}

Findings from this research suggest that issues of supply chain transparency, balancing commercial and non-profit goals, and the subsequent exclusion of producers, led to actual and potential challenges to NGOs' cognitive, moral, and sociopolitical legitimacy from producers, other development agencies, and supermarket partners alike. 


\subsection{Supply Chain Transparency: Challenges to Cognitive Legitimacy}

In many instances, producers were unfamiliar with their end markets, and therefore blamed intermediary NGOs for market fluctuations or supermarkets' inconsistent behavior. This, in turn, could lead to challenges to NGOs' cognitive legitimacy, since producers saw them as acting like a business, and sometimes interpreted their provision of services as a market-based contract.

The NGO and agency employees explained that market fluctuations were due in part to the success of their projects in fostering improved production practices that increased yields. In addition, when conditions favored the production of a certain crop, there was often a glut in the market and a decline in prices. Despite the verbal agreements that some supermarkets had with NGOs and their related producers' associations, NGO and agency employees described how supermarkets tried to take advantage of situations of oversupply to drive down prices, and otherwise used practices that NGOs felt disregarded the basis of their partnerships. These problems were often specifically cited in relation to Hortifruti, although in some cases the events dated back to before Wal-Mart owned Hortifruti, or were made with reference to a different supermarket chain. In one case, an NGO representative who helped to coordinate the relationship for Producers' Association D explained that Hortifruti still had a bad reputation among some producers due to failed relationships from the mid-2000s:

We agreed upon a price, more or less. At the moment of delivery, they don't take all of the product, or they don't want to pay the agreed upon price they didn't fulfill the agreement, and there are many, here in Honduras, who are unhappy with Wal-Mart on this level. One time they left me with 60,000 pounds of product. They placed the order and then they said no. Just like that, out of nowhere.

Another NGO employee who worked with Producers' Association A related a more recent story of how Hortifruti told them at the last minute that it already had too much product and couldn't accept their delivery, leaving the association to find a new market for a perishable product [70].

These market fluctuations and this inconsistent supermarket behavior created problems for NGOs when producers identified the producers' association, not the supermarket, as their end market. For example, one region in Honduras experienced an overproduction of a certain product during the height of the season, which flooded the market, lowered prices, and resulted in Hortifruti failing to purchase as much as it had agreed to in the pre-season. In the case of the NGO that worked with Producers' Association A, the NGO handled all commercial transactions between the grower and Hortifruti, including the production calendar, pick-up, transport, delivery, and payments. As a result, one producer blamed his loss of product on the NGO rather than on Hortifruti, saying:

Look, last year I lost quite a bit of [product]. I mean, I had a market that was supposedly formal, but then at the last minute what ends up affecting you sometimes are the employees who work for a business. They tell you they're going to take it, or you have a harvesting plan. And then at the last minute, they say, look, we're not going to be able to. (Emphasis added)

There are two aspects of this statement that stand out in terms of explaining the potential challenges to NGOs' cognitive legitimacy in market-based development projects. The first is the fact that this producer refers to "employees who work for a business" to talk about his relationship with NGO technicians. This 
suggests a potential challenge to the cognitive legitimacy of this organization, since the producer fails to categorize it as a civil society organization, seeing it instead as a market-oriented business. In addition, this producer mentions having a harvesting plan in a way that suggests that this plan formed the basis of his commitment to this market. At another point during the interview, this same producer made the comment:

There's nothing signed, but it's a commitment. They support us with inputs, credits for inputs, everything on the technical side. So that's where you enter into a commitment and say, "I'm committed to them because they give me assistance, and they give me economic support with inputs," Of course, it's an agreement and you try to honor that. Because it's not possible that after they give you a hand, you don't respond with your product.

In both of these statements, it is apparent that this producer conflated receiving technical assistance with an informal agreement, thus assuming equivalence between his non-commercial relationship with NGOs (as a constituent and aid recipient) and his vertical supply chain relationship (which included a commercial interaction). This was a sentiment that was expressed by many producers in this study; however, the agreement between the NGO and the supermarket was verbal and therefore not a formal, legally binding contract, and therefore the arrangements between NGOs and producers were constrained by this informality. In this example, the producer stopped working with Producers' Association A, and switched to selling through Producers' Association B. This example demonstrates the importance of promoting supply chain transparency and information sharing for NGOs that mediate producer relationships with supermarkets, and the impact that acting as a supply chain intermediary can have on their legitimacy vis-à-vis their constituents.

\subsection{Commercial and Non-Profit Goals: Challenges to Cognitive and Moral Legitimacy}

Balancing commercial and non-profit goals led supermarket partners and actors within the development community to question NGOs' cognitive and moral legitimacy. NGOs faced legitimacy challenges when they were seen as being aligned with one specific supermarket or as prioritizing commercial goals. While there are a handful of supermarket chains in Honduras, it was possible for producers to get locked into selling to only one because of their affiliation with a certain development project. Once a development organization entered into an agreement with one supermarket, it could prove challenging to engage with others. For example, the NGO that coordinated Producers' Association D had a formal contract, called a fideicomiso, [71] with Wal-Mart's main competitor. A national-level employee from the NGO that coordinated this arrangement explained that they'd like to enter into a similar arrangement with Wal-Mart, but that,

Of course there's a lot of competition there, since this is a massive publicity campaign, right? So of course they [Hortifruti] said, I don't know how an organization like yours could be tied to our competition. And you know, they're right. I mean, I'd feel the same way. (Emphasis added)

In this case, Hortifruti questioned the NGO's affiliation with a competing supermarket, and, since the company worried about sharing trade secrets with its competitors, this impeded partnership development.

Similarly, the technician who worked with Producers' Association B described the NGO coordinating Producers' Association A, which had a direct and close relationship with Hortifruti, by saying: 
it's just that they, it's like they want to own you. And they tell you that you have to sell to them and you can't sell to anyone else. So they close off that avenue of income. But our organization, we're an NGO that's directly an NGO, so for us there's no problem. (Emphasis added)

By referring to his own organization as "an NGO that's directly an NGO," this technician calls into question the identity of the NGO affiliated with Producers' Association A, which he believed had compromised its ability to help producers increase their incomes by aligning itself exclusively with Hortifruti. He suggested that this shut out other marketing options for the producers that received assistance from that NGO [72]. In both of these examples, the partnerships between NGOs and supermarkets impeded the ability of producers' associations to diversify vertical market outlets, which is key to their ability to reduce risk and retain bargaining power over prices in a commercial context. This finding is supported by other research, which has indicated that the oligopolistic nature of markets can be more of a constraint to smallholder market participation than the challenges of complying with standards [73]. In this way, the cognitive legitimacy of the NGO as an organization that represents civil society was called into question, as was its moral legitimacy, or the question of whether it is "the right organization for the job" [58] (p. 581) and capable of providing benefits to society.

An NGO's cognitive legitimacy could also be questioned by its partner organizations, including supermarkets themselves, for performing commercial roles. For example, an NGO employee who had both national-level responsibilities and had also worked with Producers' Association A explained how Hortifruti accused his organization of being too business-oriented and deviating from its non-profit goals by acting as a market intermediary for a producer whom they no longer directly helped with technical assistance:

Hortifruti's come out and actually got nasty saying, well, you know, why do you call yourselves a non-profit organization, you're out here picking up production from these other producers, but they're not your farmers anymore. (Emphasis added)

In this example, Hortifruti questioned whether marketing assistance was an appropriate part of the responsibilities of an NGO. Here, the NGO's role was blurred across its aid-oriented functions, such as providing technical assistance, and its commercial role, taken up to facilitate market access for producers. The NGO in this example had participated in several US-funded development projects that included partnerships with Wal-Mart; it is therefore interesting that within this context, Hortifruti would criticize its dual role of non-profit and commercial entity, and raises analytical questions about whether Hortifruti views the NGO as a partner or as a business associate.

These two examples point to the potential challenges that NGOs that perform market functions may face to their cognitive and moral legitimacy. In both situations, NGOs' commercial role in development projects led external actors to suggest that they didn't conform to their socially prescribed role, and therefore could no longer easily be categorized as an organization that represents civil society and provides societal benefits.

\subsection{Issues of Market Exclusion: Challenges to Sociopolitical Legitimacy}

Commercial pressures led NGO and agency employees, as well as technicians with the USAID project, to exclude producers from projects in some cases. The two reasons that NGO and agency representatives cited for needing to exclude producers were because individual producers consistently struggled to meet 
quality requirements, or because the NGO/agency representative wanted to restrict the size of the producers' association in order to protect its market advantage and avoid overproduction. In both of these situations, limiting the benefits of their programs to certain producers potentially challenges NGOs' sociopolitical legitimacy, although these challenges remained unrealized in this study.

In the first situation, an emphasis on meeting supermarkets' quality requirements led some development projects to exclude producers who struggled to implement new practices or to follow technicians' advice. As a technician who provided assistance to Producers' Association B explained, producers who weren't able to adapt their practices to meet supermarkets' demands for quality put the agreement between the supermarket and producers' association at risk, since the producers' association became liable for any losses incurred if that produce were subsequently rejected by the supermarket. In addition to the financial losses involved, repeated rejections could negatively affect the commercial relationship between the NGO and the supermarket.

In cases where producers struggled to meet the quality or volume demands required by this market, NGOs were put in a difficult position. For example, a technician working for the USAID project explained,

The problem is, the same goal that we have as a project doesn't allow us much leeway with people who don't comply. Because strictly speaking, over time they have to reach a certain income level. If you see that certain people, because of the way they work, aren't going to reach that level, then it's best to withdraw assistance. So, yeah, you have to make decisions, and that's the part that nobody likes, but you do it.

Although this sentiment was expressed by several technicians, they also explained that failure to comply didn't automatically lead to exclusion from development projects; one of the technicians from the USAID project reported maintaining two different lists of producers, one for those who were officially registered in the program and therefore had to demonstrate income gains, and an unofficial list for those whom they doubted would be able to achieve the necessary income improvement goals. A manager for Producers' Association A explained that, when producers struggled to meet volume demands, "We have to find new producers. That's our only option, there's no other way", since they are unable to cut producers from projects once they have been formally registered.

However, training additional producers to increase the volume that the producers' association could offer to a supermarket potentially led to another problem. In expanding the influence and benefits that their project could offer, development agencies had to be careful to avoid overproduction, which could lower prices and affect their ability to maintain their relationship with their supermarket partners, as described above. In many ways, this situation mirrors the "Faustian Bargain" which is referred to in the literature on Fair Trade and other sustainability standards to describe the inherent conflict between expanding benefits while maintaining a market niche [74,75]. For example, the manager of Producers' Association C explained,

It's not that we're exclusive, but just imagine. We're 116 producers. And we have a very reduced market here. If we have more members, if we expand the association, it means we'd have a lot more [product] than we have and we wouldn't have this market. This is the problem. More than anything this is the problem we've faced and why we don't accept more members. 
In these situations, we can observe the conflict that market-based development projects faced in trying to extend aid to as many producers as possible, while still maintaining viable commercial relationships and a competitive advantage in the marketplace.

Producer exclusion from market-based development projects indicates the potential for challenges to NGOs' sociopolitical legitimacy, although none of those interviewed posed it as an actual challenge. Since part of the socially prescribed role of NGOs, as representatives of civil society, is that they "are geared to improving the quality of life of disadvantaged people" [41] (p. 2060), then the exclusion of some producers from programs, either due to their failure to meet supermarkets' quality requirements or in order to preserve a market niche, could potentially lead to challenges to NGOs' pragmatic and moral legitimacy internally with their constituents and externally with funders and partners.

\section{Discussion}

The research presented here suggests that the producers' associations under study struggled to maintain non-commercial relationships, including partnerships with supermarkets and providing assistance to small-scale producers, while simultaneously managing their commercial role in coordinating vertical supply chains. A study of Wal-Mart's domestic tomato supply chains in Nicaragua echoes these findings, saying of producers' associations: "these organizations become primarily marketing organizations, where the business of the organization (selling a product) becomes more closely related to the business of the buyer (buying a product) than that of farmers (improving household incomes)" [50] (p. 248). These findings illustrate the difficulties of embedding philanthropic activities in market-based systems, and demonstrate how multi-stakeholder collaborations may be influenced more by commercial priorities than the elements of a partnership. Ultimately, NGOs' participation did not necessarily improve the accountability of public/private partnerships, since Hortifruti (Wal-Mart) treated the relationships like any other commercial transaction, leaving one to wonder if their contribution was intended only to provide a market, despite their CSR claims. Indeed, Hortifruti appeared to strategically use legitimacy challenges when it was commercially pragmatic, questioning NGOs' market activities when they weren't to the supermarkets' advantage, and relying on NGOs to perform them when relationships with small-scale producers would otherwise be unviable.

In the findings of this study, the majority of participants were beginning to challenge NGOs' cognitive legitimacy due to their performance of market-oriented activities. While only a few participants took the next step in Bitekine's process of social evaluation and questioned NGOs' socio-political legitimacy, these findings demonstrate the potential for a legitimacy challenge based on restrictions to providing benefits caused by market demands and pressures. This raises the question of what the potential consequences might be of this perceived mission drift and deviation from socially prescribed roles, especially as it relates to NGOs' ability to represent civil society in hybrid governance arrangements.

As explained in the review of the literature, individual challenges to an organization's legitimacy do not necessarily lead to either a legitimacy crisis or social sanctions; for example, in the earlier example the individual producer's negative judgment of Producers' Association A led him to switch which NGO he worked with, but may not lead to further repercussions if his views are not shared by other producers. In fact, while this producer switched from Producers' Association A to B, another producer who was part of this study switched from B to A, since he felt that Producers' Association B didn't handle his 
credit fairly, causing him to go into debt. Both producers were happy with the NGOs they were working with at the time, and felt that they were benefitting economically and improving their livelihoods (although each had worked with the respective producers' association for only one year).

On the other hand, key actors' perceptions, such as supermarket partners or donors, may carry more weight. In this case, it is possible that NGOs' commercial activities may lead to perceptions that these organizations are failing to meet the socially sanctioned role of contributing to development. Since NGOs are invited to participate in multi-stakeholder collaborations precisely because of their ability to represent civil society, challenges to their legitimacy in this context could undermine their participation in hybrid governance arrangements. In this context, it is has been suggested that we may also need to reconsider NGOs as an unproblematic category that assumes that these organizations are morally superior to their counterparts in the private and public sector; as Chahim and Prakash state:

Instead of assuming that all NGOs are guided by principled beliefs and serve as agents of social change, scholars need to carefully examine their motivations and the context in which they function (Prakash and Gugerty 2010a). This can lead to a more realistic and nuanced assessment of NGOs as a category of political actors with their own share of limitations and compromises [37] (p. 23).

As mentioned earlier, challenges to NGO legitimacy could also lead to a re-categorization of these organizations as "social enterprises", that combine commercial and social goals [48]. However, doing so could change the status of NGOs as civil society representatives, thus changing the basis for their participation in multi-stakeholder collaborations. On the other hand, just as NGOs survived the challenges to their organizational identity that were caused by their professionalization and de-politicization in the 1990 s, it is also possible that the general public may continue to designate NGOs as the appropriate representatives of civil society, and therefore will continue to bestow them with the cognitive and sociopolitical legitimacy that they need to participate in development projects.

\section{Conclusions}

This paper has problematized the role of civil society in hybrid governance arrangements, arguing that NGOs' commercial responsibilities create tension with their aid-oriented goals, potentially exclude producers, and can jeopardize their organizational legitimacy. While previous research has largely examined these issues at a global scale, this study provides a close analysis of the implications of the market-based roles and responsibilities of NGOs within development projects. Ultimately, partnerships are no substitute for formal contracts, and in the case presented here, the informality of the agreements between supermarkets and NGOs that worked with producers' associations led to the prioritization of commercial criteria over more aid-oriented goals. A relative lack of transparency along the supply chain and NGOs' performance of market intermediary roles led producers, other civil society actors, and even supermarkets to question the legitimacy of NGOs as they attempted to balance their commercial and aid-oriented roles and responsibilities.

While these findings appear to negate the claim that the insertion of civil society organizations into governance roles through multi-stakeholder collaborations increases the effectiveness and legitimacy of these efforts, judging NGOs and the outcomes of hybrid governance arrangements for reflecting a neoliberal 
orientation may ultimately be tautological. The role of NGOs in hybrid governance arrangements illustrates how development NGOs are products of neoliberal, hybrid governance, even as their activities are expected to ease the transition of small-scale producers into this system [23,35]. As McCarthy says in his analysis of community forestry programs, "they neglect to ask how civil society and communities are shaped for and by power, rather than merely against it" [35] (p. 1010). In this sense, NGOs may actually improve the effectiveness and legitimacy of multi-stakeholder collaborations and partnerships compared to situations where small-scale producers lack their assistance. For example, a study of small-scale producers in Thailand who had received government food safety certification found that this certification had no effect on pesticide use rates, which the authors attribute to a lack of appropriate technical assistance [76]. In cases such as these, NGOs may have a critical role to play, especially where state-based assistance is underfunded or inadequate.

In addition, we should also turn our analysis to private actors, whose participation in multi-stakeholder collaborations is intended to fulfill CSR goals, even while they outsource the responsibilities and costs of these arrangements onto NGOS. It is possible that the outcomes of multi-stakeholder collaborations would be improved if commercial organizations such as supermarkets were willing to change their processes to accommodate the needs and capacity of small-scale growers, thus forcing supermarkets to balance commercial and philanthropic priorities within their own business models, just as NGOs have been forced to do. Currently, many CSR initiatives are focused on how sustainability can be a "win-win" proposition, without fully acknowledging the inherent trade-offs and unintended consequences that come with market-based development projects.

This study also raises the question of how legitimacy challenges may vary at different scales. For example, while participants questioned NGO legitimacy, coordinating agencies such as the USAID and MCC remained immune to such challenges. How might the tensions faced by NGOs that work on the ground translate through upwards accountability to affect how public agencies engage in multi-stakeholder collaborations?

Finally, this study reminds us that, as Chahim and Prakash state, NGOs "are driven by both principled and instrumental concerns" [37] (p. 23), and are constrained, and forced to make compromises, by the system within which they operate. Therefore, in contributing to the academic literature that warns against romanticizing the role of civil society in hybrid governance, this paper also demonstrates the limitations of market-based development projects, and the challenges inherent in attempting to reform existing systems by using the same logic and methods that initially created them.

\section{Acknowledgments}

Many thanks to my doctoral advisor, Clare Hinrichs, and members of my doctoral dissertation committee, including Leland Glenna, Stephan Goetz, Karl Zimmerer, James McCarthy, and Anouk Patel-Campillo, for feedback and input on earlier drafts of this paper. I also owe a debt of gratitude to Kristal Jones and Daniel Tobin for their thoughtful and constructive comments. I am additionally appreciative of the suggestions made by two anonymous reviewers that furthered this analysis. The research for this paper was made possible and enhanced by grant support received from various agencies and programs. These include a National Science Foundation Dissertation Research Improvement Grant (Award \#1103180); a pre-doctoral Fellowship from the USDA's National Institute for Food and Agriculture (Grant 
\#2011-67011-30760); a Sustainability Seed Grant from the Penn State Institutes for Energy and the Environment; and a Penn State University College of Agricultural Sciences Graduate Research Award. The views presented here do not necessarily represent those of these funders.

\section{Conflicts of Interest}

The author declares no conflict of interest.

\section{References and Notes}

1. Bingen, J.; Serrano, A.; Howard, J. Linking farmers to markets: Different approaches to human capital development. Food Policy 2003, 28, 405-419.

2. Bitzer, V. Partnering for Change in Chains: The Capacity of Partnerships to Promote Sustainable Change in Global Agrifood Chains. Int. Food Agribus. Manag. Rev. 2012, 15, 13-38.

3. Hellin, J.; Lundy, M.; Meijer, M. Farmer organization, collective action and market access in Meso-America. Food Policy 2009, 34, 16-22.

4. Narrod, C.; Roy, D.; Okello, J.; Avedaño, B.; Rich, K.; Thorat, A. Public-private partnerships and collective action in high value fruit and vegetable suppy chains. Food Policy 2009, 34, 8-15.

5. Bäckstrand, K. Multi-stakeholder partnerships for sustainable development: Rethinking legitimacy, accountability and effectiveness. Eur. Environ. 2006, 16, 290-306.

6. Cashore, B. Legitimacy and the Privatization of Environmental Governance: How Non-State Market-Driven (NSMD) Governance Systems Gain Rule-Making Authority. Governance 2002, 15 , 503-529.

7. Spaargaren, G.; Mol, A.P.J.; Bruyninckx, H. Introduction: Governing Environmental Flows in Global Modernity. In Governing Environmental Flows: Global Challenges to Social Theory; The MIT Press: Cambridge, MA, USA, 2006; pp. 1-36.

8. Bloom, J.D. Subsidizing Sustainability: The Role of the State and Civil Society in Implementing Wal-Mart's Local Produce Sourcing Program. In Law and the Transition to Business Sustainability; Cahoy, D.R., Colburn, J.E., Eds.; Springer: Berlin, Germany, 2014; pp. 57-83.

9. Markelova, H.; Meinzen-Dick, R.; Hellin, J.; Dohrn, S. Collective action for smallholder market access. Collect. Action Smallhold. Mark. Access 2009, 34, 1-7.

10. Reed, A.M.; Reed, D. Partnerships for Development: Four Models of Business Involvement. J. Bus. Ethics 2009, 90, 3-37.

11. Stevis, D.; Bruyninckx, H. Looking through the State at Environmental Flows and Governance. In Governing Environmental Flows: Global Challenges to Social Theory; Spaargaren, G., Mol, A.P.J., Buttel, F., Eds.; The MIT Press: Cambridge, MA, USA, 2005; pp. 107-136.

12. Jamison, A. The Making of Green Knowledge: Environmental Politics and Cultural Transformation; Cambridge University Press: Cambridge, UK, 2001.

13. Edwards, M. Civil Society; Polity: Cambridge, UK, 2009.

14. Jepson, P. Governance and accountability of environmental NGOs. Environ. Sci. Policy 2005, 8, $515-524$. 
15. Schäferhoff, M.; Campe, S.; Kaan, C. Transnational Public-Private Partnerships in International Relations: Making Sense of Concepts, Research Frameworks, and Results. Int. Stud. Rev. 2009, 11, 451-474.

16. Brinkerhoff, D.W.; Brinkerhoff, J.M. Public-private partnerships: Perspectives on purposes, publicness, and good governance. Public Adm. Dev. 2011, 31, 2-14.

17. Glasbergen, P. Understanding partnerships for sustainable development analytically: The ladder of partnership activity as a methodological tool. Environ. Policy Gov. 2011, 21, 1-13.

18. Brinkerhoff, J.M. Partnership as a means to good governance: Towards an evaluation framework. In Partnerships, Governance and Sustainable Development: Reflections on Theory and Practice; Glasbergen, P., Biermann, F., Mol, A.P.J., Eds.; Edward Elgar: Cheltenahm, UK, 2007; pp. 68-89.

19. Bain, C.; Ransom, E.; Higgins, V. Special Issue: Private agri-food standards-Part 1: Contestation, hybridity and the politics of standards. Int. J. Sociol. Agric. Food 2013, 20, 1-146.

20. Henson, S. Private agrifood governance: Conclusions, observations and provocations. Agric. Hum. Values 2011, 28, 443-451.

21. Fuchs, D.; Kalfagianni, A.; Havinga, T. Actors in private food governance: The legitimacy of retail standards and multistakeholder initiatives with civil society participation. Agric. Hum. Values 2011, $28,353-367$.

22. Hatanaka, M.; Konefal, J. Legitimacy and Standard Development in Multi-stakeholder Initiatives: A Case Study of the Leonardo Academy's Sustainable Agriculture Standard Initiative. Int. J. Sociol. Agric. Food 2013, 20, 155-173.

23. Ford, L.H. Challenging Global Environmental Governance: Social Movement Agency and Global Civil Society. Glob. Environ. Polit. 2003, 3, 120-134.

24. Herlin, H. Better Safe than Sorry: Nonprofit Organizational Legitimacy and Cross-Sector Partnerships. Bus. Soc. 2013, doi:10.1177/0007650312472609.

25. Cashore, B.; Auld, G.; Newsom, D. Governing through Markets: Forest Certifcation and the Emergence of Non-State Authority; Yale University Press: New Haven, CT, USA, 2004.

26. Foucault, M. Governmentality. In The Foucault Effect; Buchell, G., Gordon, C., Miller, P., Eds.; Harvester Wheatsheaf: London, UK, 1991; pp. 87-104.

27. Gibbon, P.; Ponte, S. Global value chains: From governance to governmentality? Econ. Soc. 2008, 37, 365-392.

28. Rose, N.; Miller, P. Political Power beyond the State: Problematics of Government. Br. J. Sociol. 1992, 43, 173-205.

29. Falkner, R. Private Environmental Governance and International Relations: Exploring the Links. Glob. Environ. Polit. 2003, 3, 72-87.

30. Constance, D.H.; Bonanno, A. Regulating the global fisheries: The World Wildlife Fund, Unilever, and the Marine Stewardship Council. Agric. Hum. Values 2000, 17, 125-139.

31. Dellas, E. Partnerships for Sustainable Development in the Water Sector: Privatization, Participation and Legitimacy. In Public-Private Partnerships for Sustainable Development: Emergence, Influence and Legitimacy; Pattberg, P., Biermann, F., Chan, S., Eds.; Edward Elgar: Cheltenahm, UK, 2012; pp. 183-208.

32. Klooster, D. Environmental certification of forests: The evolution of environmental governance in a commodity network. J. Rural Stud. 2005, 21, 403-417. 
33. Bitzer, V.; Glasbergen, P.; Arts, B. Exploring the potential of intersectoral partnerships to improve the position of farmers in global agrifood chains: Findings from the coffee sector in Peru. Agric. Hum. Values 2013, 30, 5-20.

34. Gregoratti, C. Global nuts and local mangoes: A critical reading of the UNDP Growing Sustainable Business Initiative in Kenya. Agric. Hum. Values 2011, 28, 369-383.

35. McCarthy, J. Devolution in the Woods: Community forestry as hybrid neoliberalism. Environ. Plan. A 2005, 37, 995-1014.

36. Biermann, F.; Chan, M.; Mert, A.; Pattberg, P. Mulit-Stakeholder Partnerships for Sustainable Development: Does the Promise Hold? In Partnerships, Governance and Sustainable Development: Reflections on Theory and Practice; Glasbergen, P., Biermann, F., Mol, A.P.J., Eds.; Edward Elgar: Cheltenahm, UK, 2007; pp. 239-260.

37. Chahim, D.; Prakash, A. NGOization, Foreign Funding, and the Nicaraguan Civil Society. Volunt. Int. J. Volunt. Nonprofit Organ. 2014, 25, 487-513.

38. Bäckstrand, K. Are Partnerships for Sustainable Development Democratic and Legitimate? In Public-Private Partnerships for Sustainable Development: Emergence, Influence and Legitimacy; Pattberg, P., Biermann, F., Chan, S., Eds.; Edward Elgar: Cheltenahm, UK, 2012; p. 165.

39. Biermann, F.; Mol, A.P.J.; Glasbergen, P. Conclusion: Partnerships for Sustainability-Reflections on a Future Research Agenda. In Partnerships, Governance and Sustainable Development: Reflections on Theory and Practice; Glasbergen, P., Biermann, F.; Mol, A.P.J., Eds.; Edward Elgar: Cheltenahm, UK, 2007; pp. 288-299.

40. Polanyi, K. The Great Transformation: The Political and Economic Origins of Our Time; Beacon Press: Boston, MA, USA, 1944.

41. Vakil, A.C. Confronting the classification problem: Toward a taxonomy of NGOs. World Dev. 1997, 25, 2057-2070.

42. Atack, I. Four Criteria of Development NGO Legitimacy. World Dev. 1999, 27, 855-864.

43. Korten, D.C. Third generation NGO strategies: A key to people-centered development. World Dev. 1987, 15, 145-159.

44. Tallontire, A.; Opondo, M.; Nelson, V.; Martin, A. Beyond the vertical? Using value chains and governance as a framework to analyse private standards initiatives in agri-food chains. Agric. Hum. Values 2011, 28, 427-441.

45. Watkins, S.C.; Swidler, A.; Hannan, T. Outsourcing Social Transformation: Development NGOs as Organizations. Annu. Rev. Sociol. 2012, 38, 285-315.

46. Kudadjie-Freeman, C.; Richards, P.; Struik, P.C. Unlocking the Potential of Contract Farming: Lessons from Ghana; International Institute for Environment and Development: London, UK, 2008.

47. Prowse, M. Contract Farming in Developing Countries-A Review; Agence Française de Développment: Paris, France, 2012.

48. Bebbington, A. New states, new NGOs? Crises and transitions among rural development NGOs in the Andean region. World Dev. 1997, 25, 1755-1765.

49. Edelman, M. Transnational Organizing in Agrarian Central America: Histories, Challenges, Prospects. J. Agrar. Chang. 2008, 8, 229-257.

50. Wiegel, J. A New Breed of Tomato Farmers? The Effect of Transnational Supermarket Standards on Domestic Cultures of Production and Trade. Int. J. Sociol. Agric. Food 2013, 20, 237-254. 
51. Chan, S.; Muller, C. Explaining the Geographic, Thematic and Organizational Differentiation of Partnerships for Sustainable Development. In Public-Private Partnerships for Sustainable Development: Emergence, Influence and Legitimacy; Pattberg, P., Biermann, F., Chan, S., Mert, A., Eds.; Edward Elgar: Cheltenahm, UK, 2012; pp. 44-66.

52. Bolwig, S.; Ponte, S.; Du Toit, A.; Riisgaard, L.; Halberg, N. Integrating Poverty and Environmental Concerns into Value-Chain Analysis: A Conceptual Framework. Dev. Policy Rev. 2010, 28, 173-194.

53. Dolan, C.S. Virtual moralities: The mainstreaming of Fairtrade in Kenyan tea fields. Geoforum 2010, 41, 33-43.

54. González, A.A.; Nigh, R. Smallholder participation and certification of organic farm products in Mexico. J. Rural Stud. 2005, 21, 449-460.

55. Reardon, T.; Barrett, C.B.; Berdegué, J.; Swinnen, J.F.M. Agrifood Industry Transformation and Small Farmers in Developing Countries. World Dev. 2009, 37, 1717-1727.

56. Bitektine, A. Toward a Theory of Social Judgments of Organizations: The Case of Legitimacy, Reputation, and Status. Acad. Manag. Rev. 2011, 36, 51-179.

57. Deephouse, D.L.; Carter, S.M. An Examination of Differences between Organizational Legitimacy and Organizational Reputation. J. Manag. Stud. 2005, 42, 329-360.

58. Suchman, M.C. Managing Legitimacy: Strategic and Institutional Approaches. Acad. Manag. Rev. 1995, 20, 571-610.

59. Walmart Unveils Global Sustainable Agriculture Goals. Available online: http://walmartstores.com/ pressroom/news/10376.aspx (accessed on 15 October 2010).

60. Although they are legally distinct organizations, since Hortifruti is owned and operated by Wal-Mart de México y Centroámerica, participants in this study (both growers and facilitators) used these names interchangeably.

61. Gonzalez-Vega, C.; Chalmers, G.; Quiros, R.; Rodriguez-Meza, J. Hortifruti in Central America: A Case Study about the Influence of Supermarkets on the Development and Evolution of Creditworthiness among Small and Medium Agricultural Producers; United States Agency for International Development: Washington, DC, USA, 2006.

62. Berdegué, J.; Balsevich, F.; Flores, L.; Reardon, T. Central American supermarkets' private standards of quality and safety in procurement of fresh fruits and vegetables. Food Policy 2005, 30, 254-269.

63. Leguizamon, F.A.; Ickis, J.C. Tierra Fértil, Harvard Business Review: Case Study. Available online: http://hbr.org/product/tierra-fertil/an/SKE133-PDF-ENG (accessed on 17 October 2014).

64. Reardon, T.; Timmer, C.P. Transformation of Markets for Agricultural Output in Developing Countries Since 1950: How Has Thinking Changed? In Agricultural Development: Farmers, Farm Production and Farm Market; Elsevier: Amsterdam, The Netherlands, 2007; Volume 3, Chapter 55, pp. 2807-2855.

65. While producers' associations perform a similar function to cooperatives, they are often distinct in their ownership model [47]. Several participants in this study were asked why they had formed an association rather than a cooperative, and they reported that producers resist the cooperative model due to previous negative experiences with the state-owned cooperatives that were part of agrarian reform in Honduras in the 1970s. Some farmer cooperatives do still persist, especially in the coffee sector, and some of these have diversified to also include fresh fruit and vegetables [3]. 
66. Although not specified in Figure 1, in the sample for this study the producers' association that had a more exclusive relationship with Hortifruti was facilitated by an NGO that primarily received US funding, while the producers' association that had a more formal arrangement with another supermarket was organized by an NGO that received most of its funding from European governments. In general, producers' associations have emerged as a popular rural development model [3,9], and while some in Honduras were formed specifically as part of a project where Wal-Mart was involved, others were more closely associated with other development projects and supermarkets. See the methods section for more details on the producers' associations for this study.

67. These included employees who worked directly with the specific producers' association described here (as either a production manager, administrator or marketing coordinator), as well as employees who worked for the NGO at a national scale, and therefore were responsible for overseeing several producers' associations.

68. In general, the focus on producers' associations was a theme that emerged during the course of fieldwork, and therefore the fieldwork did not necessarily revolve specifically around constructing an equivalent sample for each association. An additional 10 representatives of facilitating organizations and 22 producers were interviewed as part of this research project, although they were not formally connected with producer associations. While these participants' experiences inform the overall analysis and interpretation of the subject of this paper, in interest of time and space, their perspectives are not specifically reflected in the subsequent analysis. In general, producers in this sample who did not sell through associations were either large enough not to need NGO assistance, or alternately lacked the capacity to sell to supermarket channels.

69. All interviews were conducted, transcribed and analyzed in the original Spanish language (with the exception of one interview that was done in English, according to the native language of the research respondent). The author relied on her prior experience as a certified translator (certified by the Organización Mexicana de Traductores in Spanish to English), and the counsel of a Honduran research assistant, to translate all research instruments, analyze the text and translate the quotations that are presented in subsequent sections.

70. In cases when Hortifruti rejected produce, it was done at the moment of delivery, often after producers had waited in the receiving line for several hours. Due to the perishable nature of the product, when product was rejected, it reduced producers' negotiating capacity, leading them to accept lower prices in search of a new market.

71. Under the terms of the fideicomiso, a local bank provided credit to producers, the NGO provided technical assistance, and at the moment of sale the supermarket automatically repaid the bank before returning the rest of the profits to the producer.

72. While producers in these associations were free to find other intermediaries or sell the product to local markets, the NGO that was affiliated with Producers' Association A didn't provide the same level of marketing facilitation for alternate markets, and producers in this association didn't have access to other supermarket marketing channels. A similar situation is noted by Hospes and Clancy, who note that some producers may choose not to be included in high value supply chains, but that this choice can affect their access to resources and support [77].

73. Tennent, R.; Lockie, S. Production Relations under GLOBALG. AP: The Relative Influence of Standards and Retail Market Structure. Sociol. Rural 2012, 52, 31-47. 
74. Goodman, M.K. The mirror of consumption: Celebritization, developmental consumption and the shifting cultural politics of fair trade. Geoforum 2010, 41, 104-116.

75. Ponte, S. Greener than Thou: The Political Economy of Fish Ecolabeling and Its Local Manifestations in South Africa. World Dev. 2008, 36, 159-175.

76. Schreinemachers, P.; Schad, I.; Tipraqsa, P.; Williams, P.M.; Neef, A.; Riwthong, S.; Sangchan, W.; Grovermann, C. Can public GAP standards reduce agricultural pesticide use? The case of fruit and vegetable farming in northern Thailand. Agric. Hum. Values 2012, 29, 519-529.

77. Hospes, O.; Clancy, J. Unpacking the Discourse on Social Inclusion in Value Chains. In Value Chains, Social Inclusion and Economic Development: Contrasting Theories and Realities; Helmsing, A.B., Vellema, S., Eds.; Routledge: Oxon, UK, 2012; pp. 23-41.

(C) 2014 by the author; licensee MDPI, Basel, Switzerland. This article is an open access article distributed under the terms and conditions of the Creative Commons Attribution license (http://creativecommons.org/licenses/by/4.0/). 